\title{
Water Resources of Lafayette Parish
}

\section{Introduction}

Fresh groundwater and surface water resources are available in Lafayette Parish, which is located in south-central Louisiana (fig. 1). In 2005, more than 47 million gallons per day (Mgal/d) were withdrawn from water sources in Lafayette Parish (table 1). About 92 percent $(43.7 \mathrm{Mgal} / \mathrm{d})$ of withdrawals was groundwater, and 8 percent $(3.6 \mathrm{Mgal} / \mathrm{d})$ was surface water (table 2). Public-supply withdrawals accounted for nearly 49 percent ( $23 \mathrm{Mgal} / \mathrm{d})$ of the total groundwater use, with the cities of Lafayette and Carencro using about $21 \mathrm{Mgal} / \mathrm{d}$. Withdrawals for other uses included about $10.4 \mathrm{Mgal} / \mathrm{d}$ for rice irrigation and about $8.4 \mathrm{Mgal} / \mathrm{d}$ for aquaculture. Water withdrawals in Lafayette Parish increased from $33 \mathrm{Mgal} / \mathrm{d}$ in 1995 to about 47 $\mathrm{Mgal} / \mathrm{d}$ in 2005 (fig. 2).

This fact sheet summarizes information on the water resources of Lafayette Parish, La. Information on groundwater and surface-water availability, quality, development, use, and trends is based on previously published reports listed in the references section.
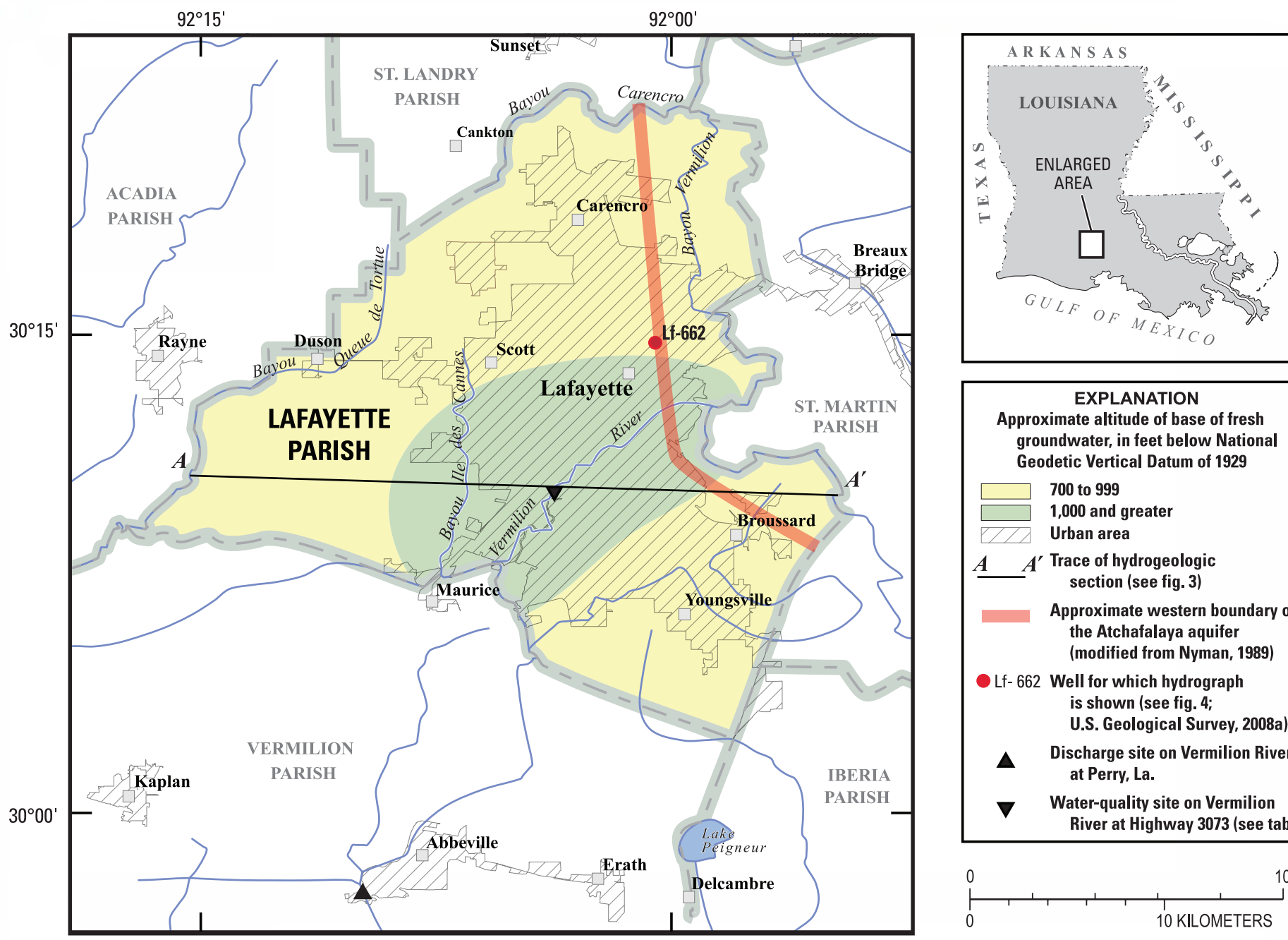

\begin{tabular}{|c|c|}
\hline \multicolumn{2}{|c|}{$\begin{array}{c}\text { EXPLANATION } \\
\text { Approximate altitude of base of fresh } \\
\text { groundwater, in feet below National } \\
\text { Geodetic Vertical Datum of } 1929\end{array}$} \\
\hline$I / 1$ & $\begin{array}{l}700 \text { to } 999 \\
1,000 \text { and greater } \\
\text { Urban area }\end{array}$ \\
\hline $\boldsymbol{A}$ & $\begin{array}{l}\text { Trace of hydrogeologic } \\
\text { section (see fig. 3) }\end{array}$ \\
\hline & $\begin{array}{l}\text { Approximate western boundary of } \\
\text { the Atchafalaya aquifer } \\
\text { (modified from Nyman, 1989) }\end{array}$ \\
\hline Lf- 662 & $\begin{array}{l}\text { Well for which hydrograph } \\
\text { is shown (see fig. 4; } \\
\text { U.S. Geological Survey, 2008a) }\end{array}$ \\
\hline & $\begin{array}{l}\text { Discharge site on Vermilion River } \\
\text { at Perry, La. }\end{array}$ \\
\hline & $\begin{array}{l}\text { Water-quality site on Vermilion } \\
\text { River at Highway } 3073 \text { (see table 4) }\end{array}$ \\
\hline
\end{tabular}

Base map modified from Official Map of Louisiana

Louisiana Department of Transportation and Development, 1986

Figure 1. Location of study area, Lafayette Parish, Louisiana. 
Table 1. Water withdrawals, in million gallons per day, by source in Lafayette Parish, La., 2005 (Sargent, 2007).

\begin{tabular}{lcc}
\hline \multicolumn{1}{c}{$\begin{array}{c}\text { Aquifer, aquifer system, or } \\
\text { major water body }\end{array}$} & Groundwater & $\begin{array}{c}\text { Surface } \\
\text { water }\end{array}$ \\
\hline Atchafalaya aquifer & 0.57 & \\
Chicot aquifer system & 43.13 & \\
Bayou Queue de Tortue & & 1.19 \\
Vermilion River & & 1.19 \\
Other water bodies & & 1.24 \\
Total & 43.70 & 3.62 \\
\hline & & \\
& &
\end{tabular}

Table 2. Water withdrawals, in million gallons per day, by category in Lafayette Parish, La., 2005 (Sargent, 2007).

\begin{tabular}{lccc}
\hline & Groundwater & Surface water & Total \\
\hline Public supply & 22.98 & 0.00 & 22.98 \\
Industrial & 0.53 & 0.00 & 0.53 \\
Power generation & 1.69 & 0.00 & 1.69 \\
Rural domestic & 2.99 & 0.00 & 2.99 \\
Livestock & 0.16 & 0.00 & 0.16 \\
Rice irrigation & 8.48 & 1.92 & 10.40 \\
General irrigation & 0.14 & 0.02 & 0.16 \\
Aquaculture & 6.73 & 1.68 & 8.41 \\
\cline { 2 - 4 } Total & 43.70 & 3.62 & 47.32 \\
\hline
\end{tabular}

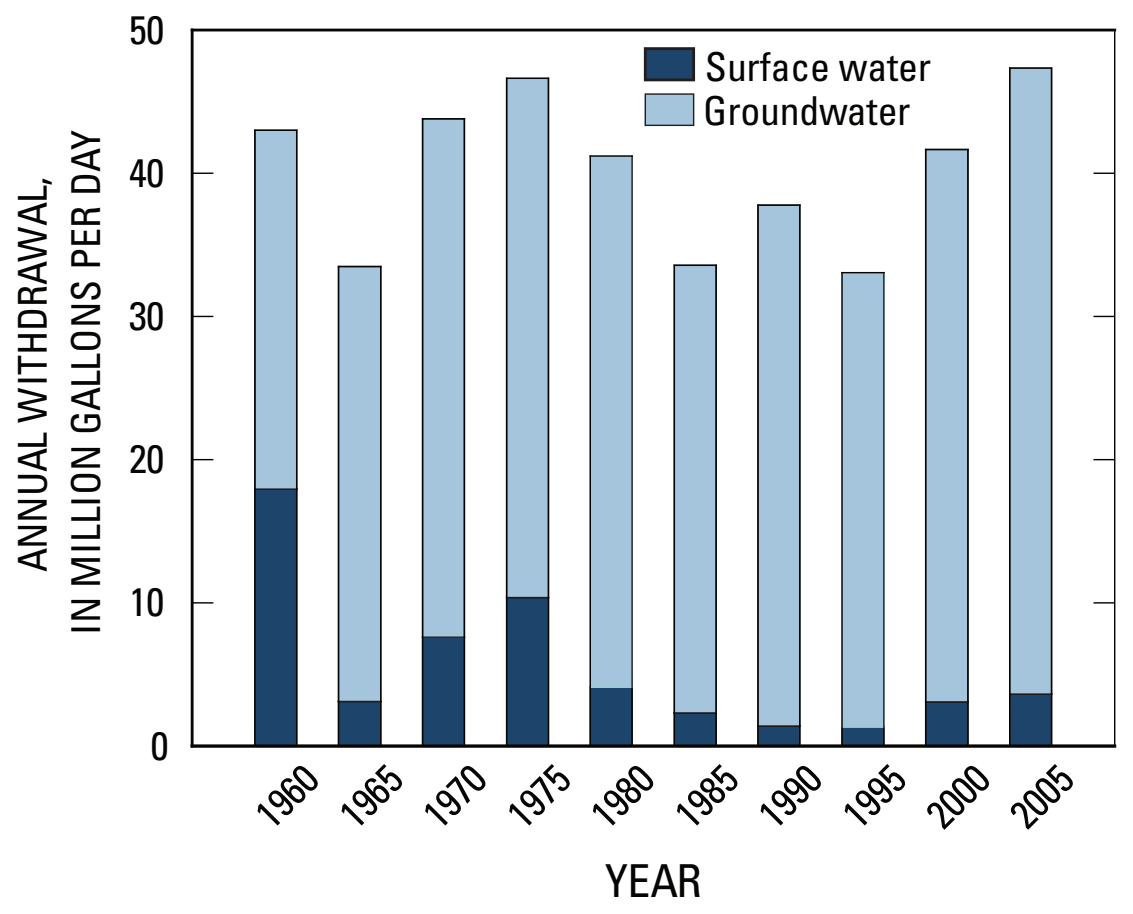

Figure 2. Water withdrawals in Lafayette Parish, La., 1960-2005.

\section{Groundwater Resources}

The primary groundwater resources of Lafayette Parish include the Chicot aquifer system and the Atchafalaya aquifer (fig. 3). The Chicot aquifer system is divided into four sand units: the shallow sand, the undifferentiated sand, the upper sand, and the lower sand. The upper and lower sands merge near the northern parish line and form the undifferentiated sand. The limited extent and lack of data on water use and water quality for the undifferentiated sand in Lafayette Parish preclude further discussion. Groundwater withdrawals by category are listed in table 2 .

The base of fresh groundwater generally ranges from about 700 to 999 feet (ft) below the National Geodetic Vertical Datum of 1929 (NGVD 29) (sea level), with depths greater than 1,000 $\mathrm{ft}$ in central parts of the parish (fig. 1). Recharge to aquifers is from rainfall in outcrop areas northwest of Lafayette Parish, infiltration from the Atchafalaya River into the Atchafalaya aquifer, vertical leakage through surficial clays, and to a lesser extent, upward leakage from the underlying Evangeline aquifer. Discharge from the aquifers is by natural flow into rivers, leakage into underlying aquifers, and withdrawal from wells. State well-registration records indicate that in 2009 there were about 4,800 active wells in Lafayette Parish, including 4,028 domestic, 361 public-supply, 321 irrigation, and 80 industrial wells.

\section{Shallow Aquifers}

The shallow aquifers in Lafayette Parish consist of the shallow sand of the Chicot aquifer system and the Atchafalaya aquifer. Most of the parish is underlain by a shallow or nearsurface clay layer known as the Chicot surficial confining unit. Within the surficial confining unit, scattered sand lenses are present and are collectively called the shallow sand of the Chicot aquifer system. These scattered sands are generally less than 20-ft thick. In 2009, there were about 110 active wells screened in the shallow sand in Lafayette Parish, and all were used for domestic purposes. Withdrawal estimates for the shallow sand were not available.

The Atchafalaya aquifer is located along the eastern edge of Lafayette Parish and primarily consists of coarse sand with interbedded layers of gravel. Well yields in the aquifer range from 4 to 150 gallons per minute (gal/min). The Atchafalaya aquifer and the Chicot aquifer system (upper sand) are hydraulically connected in the eastern part of the parish. Water levels in the Atchafalaya aquifer change with the Atchafalaya River stage and are generally higher near the river, causing water to move down gradient to the west, toward Lafayette Parish and into the Chicot aquifer system. In 2009, there were about 120 active wells screened in the Atchafalaya aquifer in Lafayette Parish, and all were used for domestic purposes. In 2005, withdrawals from the Atchafalaya aquifer were about $0.57 \mathrm{Mgal} / \mathrm{d}$. 


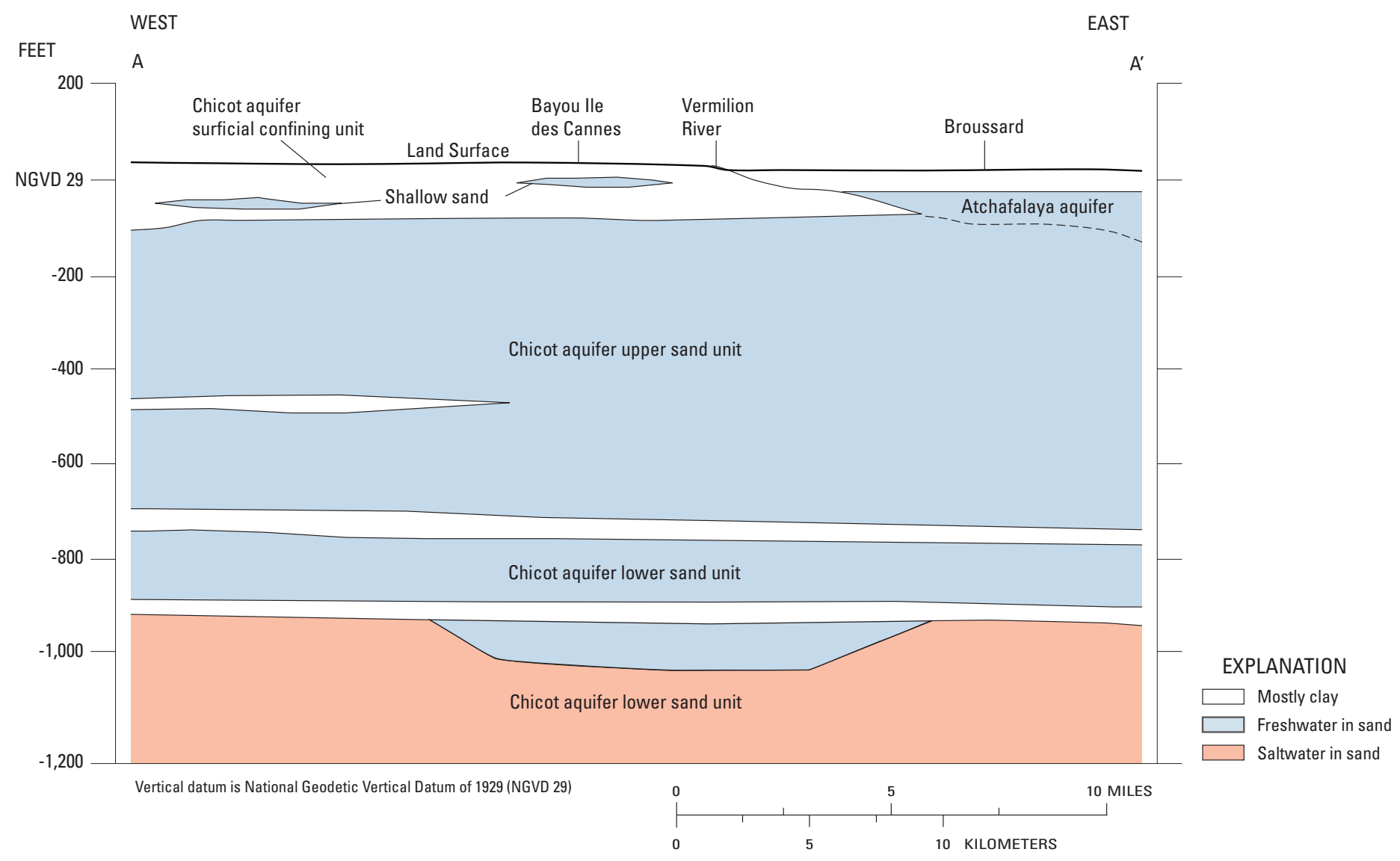

Figure 3. Generalized west-to-east hydrogeologic section through Lafayette Parish, La. (modified from Lovelace, 1999). Trace of section shown on figure 1.

Few water-quality data were available for the shallow aquifers in Lafayette Parish; however, in the shallow sand in St. Landry and St. Martin Parishes, located north and east of Lafayette Parish, iron concentrations generally exceed 5,000 micrograms per liter $(\mu \mathrm{g} / \mathrm{L})$, and hardness often exceeds 250 milligrams per liter $(\mathrm{mg} / \mathrm{L})$, which is considered very hard. Specific conductance and $\mathrm{pH}$ values in the shallow sand in St. Landry and St. Martin Parishes are similar to values in the upper sand of the Chicot aquifer system.

\section{Upper Sand}

The upper sand of the Chicot aquifer system in Lafayette Parish consists mostly of coarse sand, grading to gravel near the base of individual beds. The sand beds are generally several hundred feet thick and are separated in places by thick, discontinuous clays. Reported well yields in the upper sand have been as high as 3,500 gal/min, but most yields (93 percent) were less than $1,000 \mathrm{gal} / \mathrm{min}$. Water levels in the upper sand generally fluctuate a few feet seasonally, as shown in the hydrograph for well Lf-662 (fig. 4), located in the city of Lafayette. Water levels declined about 8-10 ft during the period 1999-2001. This decline may be due to decreased rainfall and increased withdrawals from nearby wells during this period (Don Broussard, Lafayette Utilities System, oral comm., December 2008).
A summary of selected water-quality characteristics of samples from the upper sand is provided in table 3 . Water from the upper sand ranges in hardness from soft (60 milligrams per liter $[\mathrm{mg} / \mathrm{L}]$ or less as calcium carbonate $\left.\left[\mathrm{CaCO}_{3}\right]\right)$ to very hard (greater than $180 \mathrm{mg} / \mathrm{L}$ as $\mathrm{CaCO}_{3}$ ) but in general is moderately hard $\left(61-120 \mathrm{mg} / \mathrm{L}\right.$ as $\left.\mathrm{CaCO}_{3}\right)$. The water tends to be slightly acidic $(\mathrm{pH}<7.0)$ but generally does not exceed the U.S. Environmental Protection Agency's Secondary Maximum Contaminant Levels (SMCLs) ${ }^{1}$ for drinking water for $\mathrm{pH}$ and color, as well as concentrations of chloride, iron, and dissolved solids. Locally, iron concentrations can greatly exceed the SMCL of $300 \mu \mathrm{g} / \mathrm{L}$. Manganese concentrations generally exceed the SMCL of $50 \mu \mathrm{g} / \mathrm{L}$.

State well-registration records indicate that in 2009 there were about 4,000 active wells screened in the upper sand of the Chicot aquifer system. Of these 4,000 wells, about 3,400 were used for domestic purposes.

${ }^{1}$ The SMCLs are nonenforceable Federal guidelines regarding cosmetic effects (such as tooth or skin discoloration) or aesthetic effects (such as taste, odor, or color) of drinking water. At high concentrations or values, health implications as well as aesthetic degradation might exist. SMCLs were established as guidelines for the States by the U.S. Environmental Protection Agency (1992). 


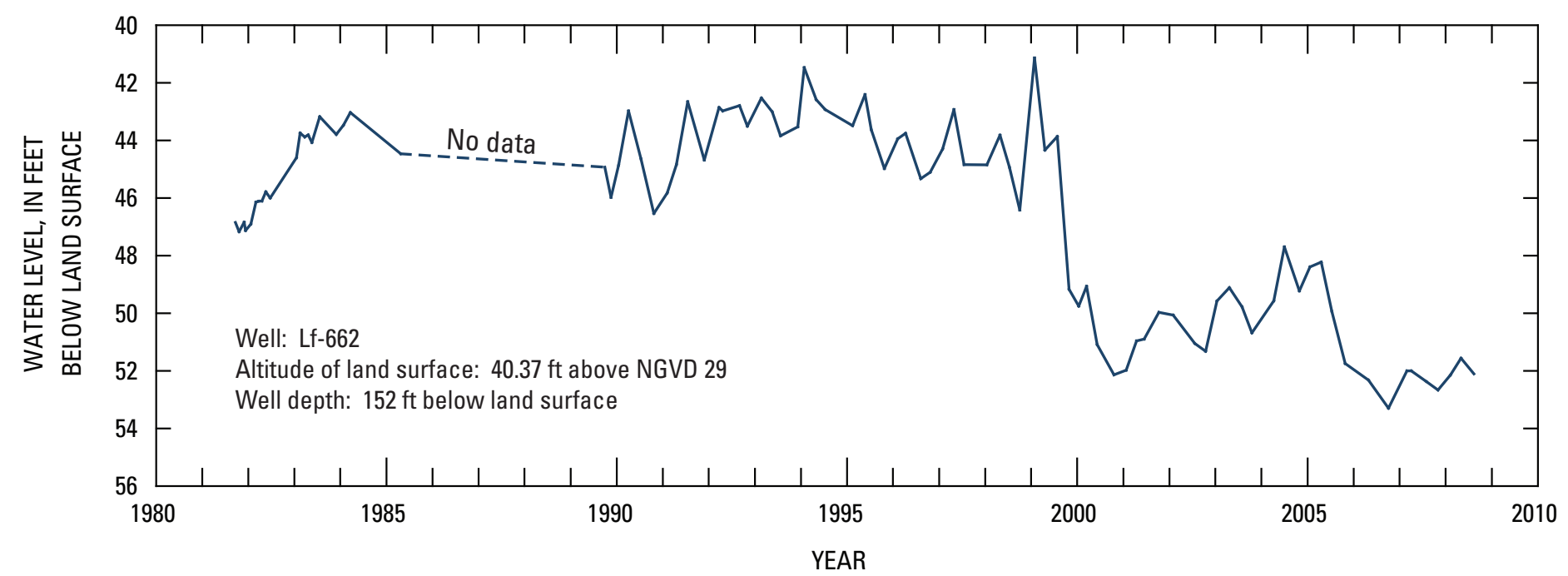

Figure 4. Water levels in well Lf-662 screened in the Chicot aquifer system, upper sand unit, in Lafayette Parish, La. (see fig. 1 for well location; U.S. Geological Survey, 2008a). Land surface is measured in feet above the National Geodetic Vertical Datum of 1929 (NGVD 29).

Table 3. Summary of selected water-quality characteristics of freshwater in the upper and lower sand units of the Chicot aquifer system in Lafayette Parish, La. (U.S. Geological Survey, 2008b).

[Values are in milligrams per liter, except as noted. ${ }^{\circ} \mathrm{C}$, degrees Celsius; PCU, platinum cobalt units; $\mu \mathrm{S} / \mathrm{cm}$, microsiemens per centimeter; SU, standard units; $\mathrm{CaCO}_{3}$, calcium carbonate; $\mu \mathrm{g} / \mathrm{L}$, micrograms per liter; <, less than; NA, not applicable; SMCL, Secondary Maximum Contaminant Level established by the U.S. Environmental Protection Agency (2006)]

\begin{tabular}{|c|c|c|c|c|c|c|c|c|c|}
\hline & $\begin{array}{c}\text { Temperature } \\
\left({ }^{\circ} \mathrm{C}\right)\end{array}$ & $\begin{array}{l}\text { Color, } \\
\text { (PCU) }\end{array}$ & $\begin{array}{c}\text { Specific } \\
\text { conductance, } \\
\text { field } \\
\left(\mu \mathrm{S} / \mathrm{cm} \text { at } 25^{\circ} \mathrm{C}\right)\end{array}$ & $\begin{array}{l}\mathrm{pH} \text {, } \\
\text { field } \\
\text { (SU) }\end{array}$ & $\begin{array}{l}\text { Hardness } \\
\left(\text { as } \mathrm{CaCO}_{3}\right)\end{array}$ & $\begin{array}{c}\text { Chloride, } \\
\text { filtered } \\
\text { (as CI) }\end{array}$ & $\begin{array}{l}\text { Iron, } \\
\text { filtered } \\
(\mu \mathrm{g} / \mathrm{L} \text { as } \\
\mathrm{Fe})\end{array}$ & $\begin{array}{c}\text { Manganese, } \\
\text { filtered } \\
\text { ( } \mu \mathrm{g} / \mathrm{L} \text { as } \mathrm{Mn})\end{array}$ & $\begin{array}{l}\text { Dissolved } \\
\text { solids, } \\
\text { filtered }\end{array}$ \\
\hline \multicolumn{10}{|c|}{ Upper sand unit of the Chicot aquifer system, 1937-2007 } \\
\hline Median & 21.0 & 5 & 298 & 6.8 & 100 & 7.8 & 30 & 170 & 195 \\
\hline 10th percentile & 19.6 & 0 & 128 & 6.0 & 34 & 3.4 & $<10$ & 1 & 106 \\
\hline 90th percentile & 22.9 & 15 & 490 & 7.4 & 180 & 19 & 2,300 & 730 & 276 \\
\hline Number of samples & 53 & 21 & 62 & 60 & 65 & 66 & 53 & 45 & 60 \\
\hline $\begin{array}{l}\text { Percentage of samples } \\
\text { that do not } \\
\text { exceed SMCLs }\end{array}$ & NA & 90 & NA & 68 & NA & 100 & 60 & 36 & 97 \\
\hline \multicolumn{10}{|c|}{ Lower sand unit of the Chicot aquifer system, 1958-1983 } \\
\hline Median & 23.5 & 5 & 450 & 7.5 & 140 & 11 & 560 & 90 & 287 \\
\hline 10th percentile & 22.1 & 0 & 365 & 7.0 & 60 & 3.4 & 96 & 16 & 234 \\
\hline 90th percentile & 24.4 & 15 & 730 & 8.0 & 180 & 53 & 760 & 110 & 455 \\
\hline Number of samples & 13 & 24 & 25 & 25 & 26 & 26 & 24 & 17 & 26 \\
\hline $\begin{array}{l}\text { Percentage of samples } \\
\text { that do not } \\
\text { exceed SMCLs }\end{array}$ & NA & 96 & NA & 96 & NA & 100 & 29 & 18 & 92 \\
\hline \multicolumn{10}{|c|}{ SMCLs } \\
\hline & NA & 15 & NA & $6.5-8.5$ & NA & 250 & 300 & 50 & 500 \\
\hline
\end{tabular}




\section{Lower Sand}

In Lafayette Parish, the lower sand of the Chicot aquifer system is hydrologically similar to the upper sand of the Chicot aquifer system. The base of the lower sand contains saltwater (greater than $250 \mathrm{mg} / \mathrm{L}$ chloride) throughout the parish. In 2009 , about 30 active wells were screened in the lower sand in Lafayette Parish. Well yields in the lower sand in the parish ranged from 16 to $4,000 \mathrm{gal} / \mathrm{min}$.

Recent water-level data are not available for the lower sand of the Chicot aquifer system in Lafayette Parish. Water levels at wells screened in the lower sand in adjacent Acadia and St. Martin Parishes declined during the mid to late 1990s but remained relatively stable from about 2000 to 2009 .

A summary of selected water-quality characteristics of freshwater in the lower sand is provided in table 3. Water from the lower sand is generally hard (hardness of $121-180 \mathrm{mg} / \mathrm{L}$ as $\mathrm{CaCO}_{3}$ ). The water generally does not exceed the SMCLs for $\mathrm{pH}$ and color, as well as for concentrations of chloride and dissolved solids. Iron and manganese concentrations generally exceed their SMCLs of $300 \mu \mathrm{g} / \mathrm{L}$ and $50 \mu \mathrm{g} / \mathrm{L}$.

\section{Surface-Water Resources}

The Vermilion River and Bayou Queue de Tortue are primary sources of fresh surface water in Lafayette Parish (fig. 1). In 2005 , about $3.6 \mathrm{Mgal} / \mathrm{d}$ of surface water was withdrawn in Lafayette Parish, including about $1.9 \mathrm{Mgal} / \mathrm{d}$ for rice irrigation and $1.7 \mathrm{Mgal} / \mathrm{d}$ for aquaculture (table 2). Other major streams in the parish include Bayou Carencro and Bayou Ile des Cannes (fig. 1). About 1.2 Mgal/d of water was withdrawn from Bayou Queue de Tortue in 2005. No water-quality data were available for the stream.

In 2005, about $1.2 \mathrm{Mgal} / \mathrm{d}$ of water was withdrawn from the Vermilion River. The average discharge for the Vermilion River at Perry (U.S. Geological Survey station number 07386980), located downstream from Lafayette Parish in adjacent Vermilion Parish (fig. 1), is 1,013 cubic feet per second (655 Mgal/d).

Analysis of water samples collected between 1983 and 1986 from the Vermilion River (table 4) indicate that, in general, the water is soft to moderately hard and generally does not exceed SMCLs for $\mathrm{pH}$ and for concentrations of chloride, sulfate, and iron. Dissolved oxygen concentrations are generally low (less than $5 \mathrm{mg} / \mathrm{L}$ ).

\section{References}

Lovelace, J.K., 1999, Distribution of saltwater in the Chicot aquifer system of southwestern Louisiana, 1995-96: Louisiana Department of Transportation and Development Water Resources Technical Report no. 66, 61 p.

Nyman, D.J., 1984, The occurrence of high concentrations of chloride in the Chicot aquifer system of southwestern Louisiana: Louisiana Department of Transportation and Development, Office of Public Works Water Resources Technical Report no. 33, 75 p.

Nyman, D.J., 1989, Quality of water in freshwater aquifers in southwestern Louisiana: Louisiana Department of Transportation and Development Water Resources Technical Report no. 42, 22 p., 28 pls.

Nyman, D.J., Halford, K.J., and Martin, Angel, Jr., 1990, Geohydrology and simulation of flow in the Chicot aquifer system of southwestern Louisiana: Louisiana Department of Transportation and Development Water Resources Technical Report no. 50, 58 p.

Table 4. Summary of selected water-quality characteristics for the Vermilion River at State Highway 3073 in Lafayette, La., $1983-86$.

[Values are in milligrams per liter, except as noted. ${ }^{\circ} \mathrm{C}$, degrees Celsius; $\mu \mathrm{S} / \mathrm{cm}$, microsiemens per centimeter; $\mathrm{SU}$, standard units; $\mu \mathrm{g} / \mathrm{L}$, micrograms per liter; $\mathrm{CaCO}_{3}$, calcium carbonate; NA, not applicable; SMCL, Secondary Maximum Contaminant Level established by the U.S. Environmental Protection Agency (2006)]

\begin{tabular}{|c|c|c|c|c|c|c|c|c|c|c|}
\hline & $\begin{array}{c}\text { Specific } \\
\text { conductance, } \\
\text { field } \\
(\mu \mathrm{S} / \mathrm{cm} \text { at } \\
\left.25^{\circ} \mathrm{C}\right)\end{array}$ & $\begin{array}{c}\text { Oxygen, } \\
\text { dissolved }\end{array}$ & $\begin{array}{l}\mathrm{pH}, \\
\text { field } \\
\text { (SU) }\end{array}$ & $\begin{array}{c}\text { Hardness } \\
\text { (as } \\
\mathrm{CaCO}_{3} \text { ) }\end{array}$ & $\begin{array}{c}\text { Calcium, } \\
\text { filtered } \\
\text { (as Ca) }\end{array}$ & $\begin{array}{l}\text { Manesium, } \\
\text { filtered } \\
\text { (as } \mathbf{M g} \text { ) }\end{array}$ & $\begin{array}{l}\text { Sodium, } \\
\text { filtered } \\
\text { (as } \mathrm{Na} \text { ) }\end{array}$ & $\begin{array}{c}\text { Chloride, } \\
\text { filtered } \\
\text { (as CI) }\end{array}$ & $\begin{array}{l}\text { Sulfate, } \\
\text { filtered } \\
\text { (as } \mathrm{SO}_{4} \text { ) }\end{array}$ & $\begin{array}{c}\text { Iron, } \\
\text { filtered } \\
\text { ( } \mu \mathrm{g} / \mathrm{L} \\
\text { as Fe) }\end{array}$ \\
\hline \multicolumn{11}{|c|}{ Vermilion River, 1983-86 } \\
\hline Median & 143 & 5.3 & 7.1 & 43 & 11 & 4.0 & 10 & 12 & 10 & 190 \\
\hline 90th percentile & 193 & 6.9 & 7.6 & 62 & 16 & 5.4 & 16 & 19 & 16 & 250 \\
\hline $\begin{array}{c}\text { Number of } \\
\text { samples }\end{array}$ & 13 & 13 & 13 & 13 & 13 & 13 & 13 & 13 & 13 & 3 \\
\hline $\begin{array}{l}\text { Percentage of } \\
\text { samples that } \\
\text { do not exceed } \\
\text { SMCLs }\end{array}$ & NA & NA & 100 & NA & NA & NA & NA & 100 & 100 & 100 \\
\hline \multicolumn{11}{|c|}{ SMCLs } \\
\hline
\end{tabular}

${ }^{1}$ Station number 07386935 (http://nwis.waterdata.usgs.gov/la/nwis/qwdata/?site_no=07386935\&amp). 
Prakken, L.B., 2003, Quality of water used for domestic supply in the Chicot aquifer system of southwestern Louisiana, 1994-2001: Louisiana Department of Transportation and Development Water Resources Technical Report no. 71, 48 p.

Prakken, L.B., and Wright, L.S., 2009, Water withdrawals and trends in ground-water levels and stream discharge in Louisiana, 1996-2005. Louisiana Department of Transportation and Development, Water Resources Technical Report no. 79, 49 p.

Sargent, B.P., 2007, Water use in Louisiana, 2005: Louisiana Department of Transportation and Development Water Resources Special Report no. 16, 133 p.

U.S. Environmental Protection Agency, 1992, Secondary Drinking Water Regulations - guidance for nuisance chemicals: U.S. Environmental Protection Agency publication EPA 810/K-92-001, 4 p., accessed July 29, 2009, at http://www.epa.gov/safewater/ consumer/2ndstandards.html.

U.S. Environmental Protection Agency, 2006, 2006 Edition of the drinking water standards and health advisories: Washington, D.C., U.S. Environmental Protection Agency, Office of Water, $12 \mathrm{p}$.

U.S. Geological Survey, 2008a, Ground-water levels for Louisiana: U.S. Geological Survey digital dataset, accessed May 22, 2008, at http://nwis.waterdata.usgs.gov/la/nwis/gwlevels.

U.S. Geological Survey, 2008b, Water-quality samples for Louisiana: U.S. Geological Survey digital dataset, accessed May 22, 2008, at http://nwis.waterdata.usgs.gov/la/nwis/qwdata.

U.S. Geological Survey, 2008c, StreamStats: U.S. Geological Survey digital dataset, accessed December 5, 2008, at http://streamstats. usgs.gov/gagepages/HTML/07386980.htm.

\section{By Robert B. Fendick, Jr., Jason M. Griffith, and Lawrence B. Prakken}

\section{For additional information, contact:}

Director, USGS Louisiana Water Science Center 3535 S. Sherwood Forest Blvd., Suite 120

Baton Rouge, LA 70816

E-mail: dc_la@usgs.gov

Fax: (225) 298-5490

Telephone: (225) 298-5481

Home Page: http://la.water.usgs.gov
This fact sheet was published by the U.S. Geological Survey, in cooperation with the Louisiana Department of Transportation and Development (DOTD). Thanks are given to Zahir "Bo" Bolourchi, Director, Water Resources Programs, Louisiana Department of Transportation and Development, who contributed to the content and design of the fact sheet. 